\title{
Penerapan Pendekatan Saintifik Dengan Media Komik Dalam Peningkatan Pembelajaran IPS Tentang Perjuangan Mempersiapkan Kemerdekaan Indonesia Pada Siswa Kelas V SD Negeri 2 Kebulusan Tahun Ajaran 2017/2018
}

\author{
1,2,3 Universitas Sebelas Maret \\ sulistiyanika56@gmail.com
}

Ika Sulistiyani ${ }^{1}$, M. Chamdani ${ }^{2}$, Joharman ${ }^{3}$

\section{Article History}

accepted 01/02/2019

\begin{abstract}
The Use of Scientific Approach Using Comic Media in Improving Social Science Learning about the Struggle of Reaching the Independent of Indonesia for the Fifth-Grade Students of SD Negeri 2 Kebulusan in the Academic Year of 2017/2018. The objective of this research was to improve the social science learning about the struggle of reaching the independent of Indonesia. This research is a collaborative Classroom Action Research (CAR) conducted within three cycles. Subjects of this research were teacher and the fifth-grade students of SD Negeri 2 Kebulusan. The data were collected from the teacher, fifth-grade students, and documents. The validity of data in this research was analyzed using triangulation of sources and triangulation of technique. Data were analyzed using qualitative data analysis namely data reduction, data display, and drawing conclusion. The conclusion of this research is the use of scientific approach using comic media can improve social science learning about the struggle of reaching the independent of Indonesia for the fifth-grade students of SD Negeri 2 Kebulusan in the academic year of 2017/2018.
\end{abstract}

Keywords: scientific approach, comic media, social science learning

\section{Abstrak}

Tujuan penelitian ini yaitu meningkatkan pembelajaran IPS tentang perjuangan mempersiapkan kemerdekaan Indonesia. Penelitian ini merupakan penelitian tindakan kelas kolaboratif yang dilaksanakan dalam tiga siklus. Subjek penelitian ini adalah guru dan siswa kelas V SD Negeri 2 Kebulusan. Sumber data penelitian ini yaitu guru, siswa, dan dokumen. Validitas yang digunakan pada penelitian ini yaitu validitas isi, triangulasi teknik dan triangulasi sumber. Teknik analisis data pada penelitian ini yaitu reduksi data, penyajian data, dan penarikan kesimpulan. Simpulan dari penelitian ini adalah penerapan pendekatan saintifik dengan media komik dapat meningkatkan pembelajaran IPS tentang perjuangan mempersiapkan kemerdekaan Indonesia ditandai dengan meningkatnya hasil belajar siswa.

Kata Kunci: Pendekatan Saintifik, Media Komik, Pembelajaran IPS 


\section{PENDAHULUAN}

Pembelajaran memiliki tujuan yang dapat ditinjau dari beberapa aspek. Salah satu pembelajaran yang ada di tingkat sekolah dasar yaitu IPS (IImu Pengetahuan Sosial). Buchari (Susanto, 2013: 141) menyatakan bahwa IPS di sekolah dasar dimaknai sebagai kegiatan pendidikan yang mengupas masalah manusia dalam lingkungan fisik dan sosialnya. Bahan materinya diperoleh dari berbagai ilmu sosial, seperti: sejarah, sosiologi, geografi, antropologi, ekonomi, psikologi, dan politik.

IPS memiliki beberapa tujuan agar siswa: a) mengenal konsep dalam kehidupan masyarakat dan lingkungan, b) memiliki kemampuan dasar untuk berpikir logis dan kritis, rasa ingin tahu, inkuiri, memecahkan masalah, dan keterampilan dalam kehidupan sosial, c) berkomitmen dan sadar terhadap nilai-nilai sosial dan kemanusiaan, serta d) memiliki kemampuan berkomunikasi, bekerja sama, dan berkompetisi dalam masyarakat yang majemuk, di tingkat lokal, nasional, dan global, Badan Standar Nasional Pendidikan (2006: 175).

Tercapainya tujuan tersebut tidaklah mudah, hal ini dikarenakan IPS mengkaji seperangkat peristiwa, fakta, konsep, dan generalisasi yang berkaitan dengan isu sosial. Kajian IPS tersebut merupakan hal abstrak bagi siswa, maka guru sebagai pemandu jalannya pembelajaran perlu mengkonkretkan materi pembelajaran sehingga dapat membuat siswa aktif dan antusias dalam belajar.

Berdasarkan hasil observasi yang dilakukan peneliti di SDN 2 Kebulusan pada Rabu, 15 November 2017, menunjukkan bahwa hasil belajar IPS siswa kelas V tergolong rendah. Dari data nilai UTS I tahun ajaran 2017/2018 menunjukkan dari 30 siswa, hanya 13 siswa yang mencapai nilai KKM yaitu 64. Dengan kata lain siswa yang mencapai KKM sebanyak 43,3\% dan 56,7\% belum mencapai KKM.

Hasil belajar yang rendah tersebut dapat terjadi karena beberapa faktor, diantaranya pembelajaran lebih menekankan pada hafalan materi, belum mengaktifkan siswa, dan pembelajaran yang didominasi dengan ceramah oleh guru. Dari kondisi pembelajaran tersebut, maka diperlukan solusi untuk meningkatkan pembelajaran IPS yang dapat dilihat dari ketercapaian hasil belajar siswa. Salah satu pendekatan pembelajaran yang tepat untuk pembelajaran IPS yaitu pendekatan saintifk dengan media komik.

Pendekatan saintifik adalah proses pembelajaran yang dirancang agar siswa aktif mengkonstruksi konsep, hukum atau prinsip melalui tahapan-tahapan mengamati untuk menemukan masalah, merumuskan masalah \& hipotesis, mengumpulkan data dengan berbagai teknik, menganalisis data, menyimpulkan, dan mengkomunikasikan temuannya, Daryanto (2014: 51). Menurut Armadi (2017: 65) pendekatan saintifik melibatkan keterampilan proses sains dan mengembangkan karakter siswa. Sedangkan Sani (2015: 53-54) mengemukakan bahwa pembelajaran dengan pendekatan saintifik terjadi dengan berbagai aktivitas, yaitu mengamati, menanya, mengumpulkan informasi, menalar, dan komunikasi. Jadi, dapat disimpulkan bahwa pendekatan saintifik adalah kegiatan pembelajaran yang didesain agar siswa aktif mengkonstruk konsep, hukum atau prinsip melalui tahap mengamati, menanya, mencoba atau mengumpulkan informasi, menalar, dan mengomunikasikan temuannya.

Selain penerapan pendekatan pembelajaran, kegiatan pembelajaran dapat didukung dengan adanya media yang berfungsi sebagai pengantar pesan antara guru dan siswa. Salah satu media pembelajaran yang dapat mendukung pendekatan saintifik adalah media komik.

Briggs (Padmono 2011: 11) menyatakan media sebagai segala alat fisik yang digunakan untuk menyajikan pesan dan merangsang siswa untuk belajar. Daryanto (2015: 126) mengemukakan komik sebagai bentuk kartun yang mengungkapkan karakter dan menerapkan suatu cerita dalam urutan yang erat hubungannya dengan gambar. Pitaloka dan Sumardjono (2017: 485) menyatakan bahwa komik merupakan cerita tertulis dan bergambar dalam bentuk percakapan sederhana yang dirancang 
untuk menyampaikan sebuah pesan tertentu. Jadi, dapat disimpulkan bahwa komik adalah gambar kartun berkarakter yang memiliki balon percakapan serta unsur cerita yang ringkas dengan alur berurutan yang dirancang untuk menyampaikan sebuah informasi.

Pendekatan saintifik dengan media komik adalah suatu cara atau inovasi dalam kegiatan pembelajaran yang didesain agar siswa dapat mengonstruksi konsep, hukum atau prinsip melalui tahap mengamati, menanya, mencoba, menalar, dan mengomunikasikan temuannya dengan memanfaatkan media komik yang digunakan untuk membantu siswa memahami konsep dalam materi pembelajaran, penerapannya meliputi: (1) mengamati media komik, (2) menanya dengan media komik, (3) mencoba dengan media komik, (4) menalar, dan (5) mengomunikasikan.

Berdasarkan uraian di atas, maka rumusan masalah dalam penelitian ini yaitu apakah penerapan pendekatan saintifik dengan media komik dapat meningkatkan pembelajaran IPS tentang perjuangan mempersiapkan kemerdekaan Indonesia pada siswa kelas V SDN 2 Kebulusan Tahun Ajaran 2017/2018?

Penelitian ini bertujuan untuk meningkatkan pembelajaran IPS tentang perjuangan mempersiapkan kemerdekaan Indonesia melalui penerapan pendekatan saintifik dengan media komik pada siswa kelas V SD Negeri 2 Kebulusan tahun ajaran 2017/2018.

\section{METODE}

Penelitian ini dilaksanakan di SDN 2 Kebulusan. Subjek penelitian ini adalah siswa kelas V SDN 2 Kebulusan tahun ajaran 2017/2018 yang berjumlah 30 siswa yang terdiri dari 14 siswa laki-laki dan 16 siswa perempuan.

Alat pengumpul data yaitu lembar tes, lembar observasi dan pedoman wawancara. Analisis data terdiri dari reduksi data, penyajian data, dan penarikan kesimpulan. Penelitian ini merupakan penelitian tindakan kelas kolaboratif antara peneliti sebagai perencana dan guru kelas $\mathrm{V}$ sebagai pelaksana tindakan. Kegiatan observasi dilakukan oleh peneliti dan dibantu oleh dua orang teman sejawat.

Uji validitas pada penelitian ini yaitu validitas isi dengan menggunakan teknik triangulasi teknik dan sumber. Triangulasi merupakan penggabungan dari berbagai sumber data dan teknik pengumpulan data yang telah ada (Sugiyono, 2012: 330). Analisis data dilakukan dengan tiga tahapan, yaitu (1) reduksi data, (2) penyajian data, dan (3) penarikan kesimpulan.

Indikator kinerja penelitian pada aktivitas guru, respon siswa, dan tes hasil belajar siswa dengan $\mathrm{KKM}=75$ sebesar $85 \%$. Penelitian dilaksanakan selama 3 siklus dengan lima pertemuan. Setiap siklus melalui 4 tahapan sesuai dengan pendapat Arikunto (2013: 131-140) yaitu (1) perencanaan, (2) pelaksanaan, (3) pengamatan, dan (4) refleksi.

\section{HASIL DAN PEMBAHASAN}

Penelitian tindakan kelas ini dilaksanakan selama tiga siklus dengan menerapkan pendekatan saintifik dengan media komik yang dilaksanakan melalui: (1) mengamati media komik, (2) menanya dengan media komik, (3) mencoba dengan media komik, (4) menalar, dan (5) mengomunikasikan.

Tindakan mengenai penerapan pendekatan saintifik dengan media komik dari siklus I sampai siklus III berjalan dengan baik. Berikut merupakan data hasil perbandingan persentase ketuntasan hasil belajar IPS pada siklus I, II, dan III. 
Volume 7 Nomor 1 Tahun 2019

Tabel 1. Perbandingan Persentase Tes Hasil Belajar IPS Tiap Siklus

\begin{tabular}{|c|c|c|}
\hline \multirow[t]{2}{*}{ Siklus } & \multicolumn{2}{|c|}{$\begin{array}{c}\text { Ketuntasan Hasil Tes } \\
(\%)\end{array}$} \\
\hline & Tuntas & $\begin{array}{l}\text { Belum } \\
\text { Tuntas }\end{array}$ \\
\hline Siklus I & $75 \%$ & $25 \%$ \\
\hline Siklus II & $88,33 \%$ & $11,67 \%$ \\
\hline Siklus III & $96,67 \%$ & $3,33 \%$ \\
\hline & $88,33 \%^{\mathrm{S}}$ & \\
\hline $100 \%$ & & \\
\hline $80 \%$ & & \\
\hline $60 \%$ & & \\
\hline $40 \%$ & & \\
\hline $20 \%$ & & \\
\hline & Siklus II S & \\
\hline
\end{tabular}

Gambar 1. Perbandingan Persentase Hasil Tes IPS Tiap Siklus

Berdasarkan tabel 1 dan gambar 1, dapat disimpulkan bahwa persentase ketuntasan tes hasil belajar IPS mengalami peningkatan dari siklus I sampai siklus III. Pada siklus I 75\%, siklus II 88,33\%, dan siklus III 96,67\%, sehingga dapat disimpulkan bahwa hasil tes IPS dengan $\mathrm{KKM}=75$ sudah mencapai indikator kinerja penelitian sebesar $85 \%$.

Dengan demikian penerapan pendekatan saintifik dengan media komik dapat meningkatkan pembelajaran yang diketahui dari meningkatnya tes hasil belajar siswa dari siklus I sampai siklus III. Hal ini karena penerapan pendekatan saintifik dengan media komik berdampak positif terhadap siswa. Siswa menjadi aktif dan percaya diri untuk mengungkapkan pendapatnya. Hasil ini sejalan dengan penelitian yang dilakukan oleh oleh Fahmi (2017) yang menyatakan bahwa pendekatan saintifik dapat meningkatkan aktivitas dan hasil belajar IPS. Selanjutnya, Akbar (2015) juga mengemukakan bahwa media komik berbasis pendekatan saintifik dapat menumbuhkan minat belajar siswa yang memperoleh nilai sebesar $100 \%$ siswa merespon positif.

\section{SIMPULAN}

Berdasarkan hasil penelitian dapat disimpulkan bahwa penerapan pendekatan saintifik dengan media komik dapat meningkatkan pembelajaran IPS tentang perjuangan mempersiapkan kemerdekaan Indonesia pada siswa kelas V SDN 2 Kebulusan tahun ajaran 2017/2018 yang dibuktikan dengan peningkatan hasil belajar siswa.

Peneliti memberikan beberapa saran agar kualitas penbelajaran semakin meningkat, yaitu: (1) bagi guru, guru sebaiknya meningkatkan kompetensi pedagogik dan profesionalnya dengan menciptakan pembelajaran yang dapat membuat siswa antusias dan berpartisipasi secara aktif. (2) bagi siswa, siswa harus lebih fokus, aktif, dan memiliki semangat belajar yang tinggi dengan memperhatikan pembelajaran. (3) bagi sekolah, pihak sekolah hendaknya mendukung dan memfasilitasi guru untuk menerapkan pendekatan dan media pembelajaran yang inovatif untuk meningkatkan kualitas pembelajaran sehingga dapat memberikan dampak positif terhadap kemajuan siswa, guru, dan sekolah. (4) bagi peneliti selanjutnya, sebaiknya melaksanakan 
penelitian pengembangan mengenai penerapan pendekatan saintifik dengan media komik.

\section{DAFTAR PUSTAKA}

Akbar, O.A. (2015). Minat Belajar Siswa terhadap Media Komik Berbasis Pendekatan Saintifik pada Materi Sistem Pencernaan Kelas XI SMA. BioEdu Berkala Ilmiah Pendidikan Biologi, 4 (1): 750-753. Diperoleh pada 7 November 2017, dari http://www.jurnalmahasiswa.unesa.ac.id/index.php/ bioedu/article/view/10929.

Arikunto, S. (2013). Prosedur Penelitian. Jakarta: PT Rineka Cipta.

Armadi, A. (2017). Pendekatan Scientific dalam Pembelajaran Tematik Terpadu di SD. Jurnal Autentik, 1 (1): 55-67. Diperoleh pada 11 Desember 2017, dari http://www.ajppd. com/index.php/autentik/article/download/13/13/.

Badan Standar Nasional Pendidikan. (2006). Standar isi untuk Satuan Pendidikan Dasar dan Menengah, Standar Kompetensi dan Kompetensi Dasar SD/MI. Jakarta: Departemen Pendidikan Nasional.

Daryanto. (2014). Pendekatan Pembelajaran Saintifik Kurikulum 2013. Yogyakarta: Gava Media.

Daryanto. (2015). Media Pembelajaran. Bandung: PT Sarana Tutorial Nurani Sejahtera.

Fahmi, M.N. (2017). Penerapan Pendekatan Saintifik untuk Meningkatkan Aktivitas dan Hasil Belajar Siswa pada Mata Pelajaran IPS Kelas IV SDN Tambakromo 2 Ngawi. Jurnal Pendidikan Dasar Nusantara, 3 (1): 106-117. Diperoleh pada 29 November $2017 \quad$ dari http://www.ojs.unpkediri.ac.id /index.php/pgsd/article/download/749/571/.

Padmono. H.Y. (2011). Media Pembelajaran. Surakarta: FKIP UNS.

Pitaloka, S.E.D \& Sumardjono. (2017). Pengembangan Media Komik dengan Model Discovery Learning untuk Mata Pelajaran PPKN Subtema Bumi Kelas 2 SD. EJurnal Mitra Pendidikan, 1 (5): 485-495. Diperoleh pada 7 November 2017, pada http://www.e-jurnalmitrapendidikan.com/index. php/e-jmp/article/view/95/56.

Sani, R.A. (2015). Pembelajaran Saintifik untuk Implementasi Kurikulum 2013. Jakarta: PT Bumi Aksara.

Sugiyono. (2012). Metode Penelitian Pendidikan. Bandung: Alfabeta.

Susanto, A. (2013). Teori Belajar dan Pembelajaran di Sekolah Dasar. Jakarta: Prenadamedia Group. 